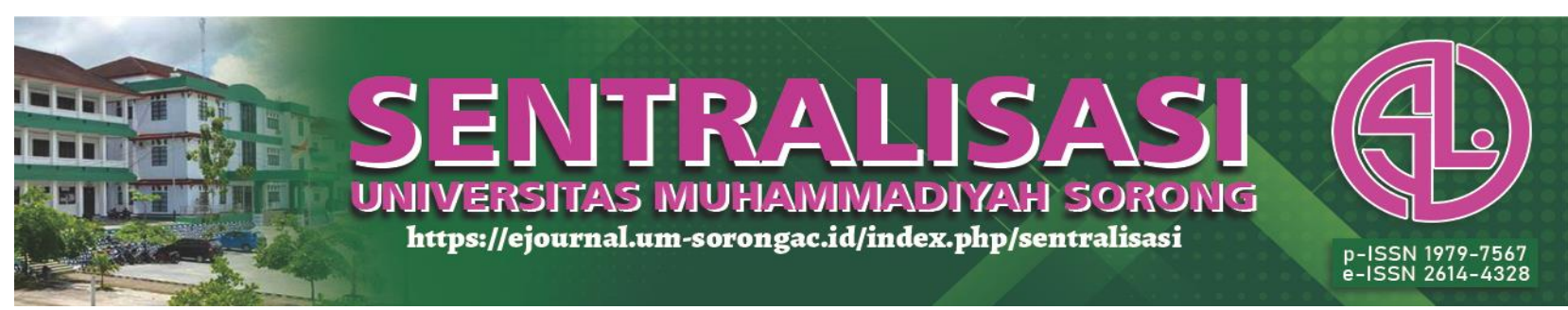

\title{
Determinants of Good Corporate Governance (Empirical Studies on Companies Listed on The IDX)
}

\author{
Riza Praditha', ${ }^{1}$ Megawati ${ }^{2}$, Lasty Agustuty ${ }^{3}$ \\ ${ }^{1,2}$ Accounting Departement, STIE Tri Dharma Nusantara Makassar, Indonesia \\ ${ }^{3}$ Financial Management Departement, STIE Tri Dharma Nusantara Makassar, Indonesia \\ E-mail :* rizapradithaa@ gmail.com \\ *corresponding author
}

direvisi: 30/12/2021 dipublikasikan: 08/01/2022

\begin{abstract}
Abstrak. Studi ini bertujuan untuk mengukur pengaruh dari konsentrasi kepemilikan, ukuran perusahaan dan leverage sebagai determinan dari implementasi good corporate governance. Desain penelitian ini adalah kuantitatif. Populasi yang digunakan adalah 45 perusahaan yang terindex LQ45 di Bursa Efek Indonesia dan dengan metode Purposive Sampling, diperoleh 17 perusahaan dengan 3 tahun pengamatan, sehingga jumlah sampel dalam penelitian ini adalah 51. Hasil penelitian menunjukkan bahwa konsentrasi kepemilikan, ukuran perusahaan dan leverage memberikan pengaruh yang positif dan signifikan terhadap besaran implementasi good corporate governance baik secara parsial maupun simultan..
\end{abstract}

Kata kunci: Good Corporate Governance, Konsentrasi kepemilikan, Leverage

Abstract. The purpose of this study is the role of ownership concentration, firm size, and leverage in influencing good corporate governance. This research design is quantitative. The population used is 45 companies indexed LQ45 on the Indonesia Stock Exchange and with the Purposive Sampling method, obtained 17 companies with 3 years of observation, so the number of samples in this study is 51. The results show that the concentration of ownership, company size, and leverage have a significant effect. The test results show a positive and significant effect on the implementation of corporate governance partially for each variable and simultaneously for all variables.

Key Words: Good Corporate Governance, The Ownership Concentration, Leverage.

\section{Introduction}

Agency problems in agency relationships often arise because of the separation between the ownership and control functions in the company's management. Agency theory tries to explain the most effective and efficient contracts or cooperation to avoid conflicts in agency relationships and Good Corporate Governance is the company's response to overcome these conflicts (Rahayuningsih, 2013); (Bone and Ponto, 2017); (Kebon \& Suryanawa, 2017).

Jensen and Meckling (1976) in his agency theory says that there is an asymmetric relationship between the agent and the principal which ultimately causes conflict between the two. Agency conflicts often occur in companies because of the possibility that managers often ignore the interests of investors, thus triggering agency costs. Managers as operational executives in the company know more about the condition of the company than the owners. This is because managers act as agents while company owners or shareholders act as principals, so that managers are fully obliged to give signals about the condition of the company to shareholders (Praditha et 


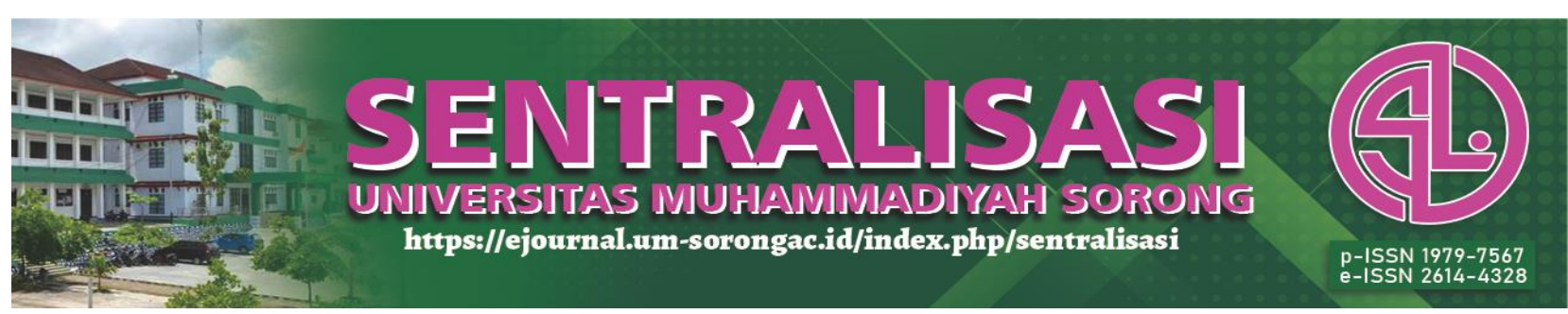

al., 2020); (Rura, 2010); (Dallas, 2018); (Taman \& Nugroho, 2011). Agency theory tries to explain the most effective and efficient contracts or cooperation to avoid conflicts in agency relationships and Good Corporate Governance is the company's response to overcome these conflicts (Bone and Ponto, 2017: 100); (Jao \& Pagalung, 2011).

The agency concept in agency theory can explain the concept of Corporate Governance in which this concept is expected to provide confidence to investors in ensuring the acceptance of the expected return from investments invested in the company. Corporate governance is closely related to investor confidence in managers as executors in the company that will provide benefits. In addition, there is also a sense of trust that managers will not embezzle or invest in projects that do not provide profits for investors (Taman \& Nugroho, 2011).

Good Corporate Governance according to Franita (2018) is a concept that regulates and provides supervision in the ongoing business control process. The main objective in the implementation of corporate governance is to increase the value of the company through increasing the value of shares. In addition, without ignoring the interests of other stakeholders such as employees, creditors, and the community, good corporate governance can also be a form of accountability to shareholders. The main success key to creating good corporate governance is to build a good supervision and control system (Jao \& Pagalung, 2011); (Meitha \& Tuzahro, 2009). Good Corporate Governance is also a regulation regarding the division of tasks and responsibilities between parties who have certain interests in the company (Sochib, 2016). Wibowo (2010) defines that Good Corporate Governance as a system consisting of processes and structures (mechanisms) that control and coordinate various participants who take part in the management of the company. Meanwhile, according to Meitha \& Tuzahro (2009), Good Corporate Governance describes the relationship between stakeholders, including investors, management, and the community. It also explains the relationships that occur within the company to determine the direction of the company's performance goals (Worokinasih \& Zaini, 2020); (Hormati, 2009); (Al-Shetwi, 2011).

The Indonesian Institute for Corporate Governance developed a quality measurement model of corporate governance. This model uses an index number to determine quality, known as the Corporate Governance Perception Index (CGPI) (Ramadhan \& Laksito, 2019). Good Corporate Governance is considered to be a concept and process as well as a structure used by companies to achieve business success and corporate accountability. In addition, corporate governance can assist in realizing value for stakeholders, especially investors. Good Corporate Governance is also considered to be a representation of a good company condition and has a high value. Weak Good Corporate Governance will show selfish actions and ignore the interests of other stakeholders (Franita, 2018); (Taman \& Nugroho, 2011).

Good Corporate Governance has become a topic of discussion in Indonesia since the 


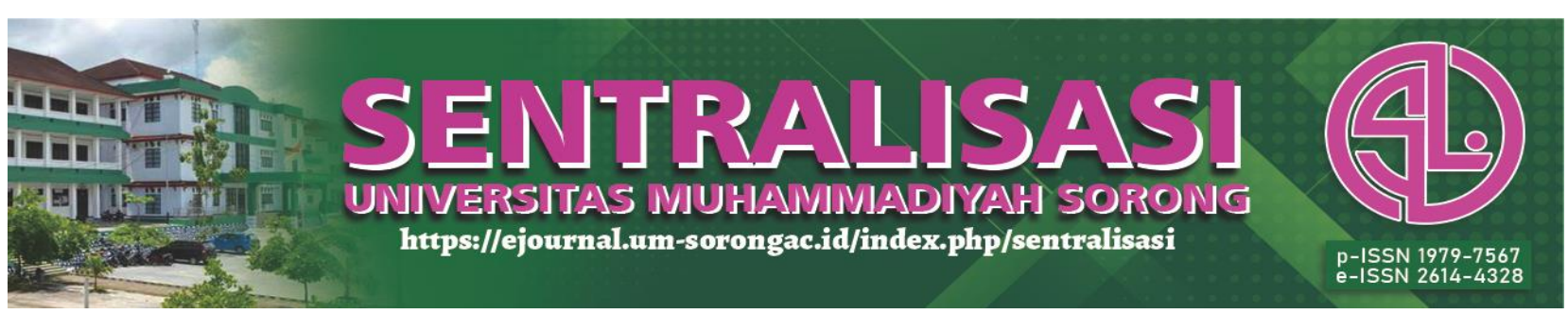

prolonged economic crisis in 1998, which is considered as a result of weak corporate governance in Indonesian companies. Since then, research on good corporate governance has been increasingly carried out as a form of thought contribution for companies in making policies to increase company value.

The issue of corporate governance cannot be separated from the supervision of stakeholders, especially shareholders, so that research on the quality of corporate governance becomes interesting and important to do. In addition, corporate governance reporting will always be one of the main highlights of investors and potential investors in assessing the quality of the company. therefore, companies need to know and understand the factors that can influence policies in implementing good governance within the company. In addition, the varied results of research on good corporate governance (such as that conducted by Franita, 2018; Taman \& Nugroho, 2011, Worokinasih \& Zaini, 2020; Hormati, 2009; Al-Shetwi, 2011) is one of the attractions of doing this research.

\section{Research Method}

\section{Conceptual Frameworks and Hypothesis Development}

Good corporate governance has various determinant factors such as ownership concentration, company size, and leverage. How and who has total control over the company or most and or wholly ownership of the company is the meaning of concentration of ownership. Ownership is said to be more concentrated if achieving dominance or majority control requires the combination of fewer investors. If the controlling company is concentrated in a few investors in a small number, then the control system will be easier to implement when compared to the controller in large numbers. However, concentrated ownership also has lower control power when compared to large shareholders, because investors still have to coordinate to exercise their control rights. On the other hand, the concentrated ownership mechanism has less opportunity for actions that may be detrimental to other investors (Taman \& Nugroho, 2011); (Aspan, 2017); (Dallas, 2018).

The size of the company which can be measured from the number of sales, market capitalization, and total assets of the company can also be a determining factor for the quality of governance in a company. the larger the size of a company, the greater the opportunity for the company to implement good governance to make the concept of governance in the company more qualified (Hormati, 2009). In addition, there is a leverage factor that is also considered capable of influencing the quality of governance within a company. this ratio describes the capital capacity of the company and the extent to which the proportion of funding is obtained from other parties. The larger the portion of the debt, the greater the possibility of obtaining profit in operations. But on the other hand, high debt will have a high risk of bankruptcy (Sulyanti, 2011); (Rahayuningsih, 


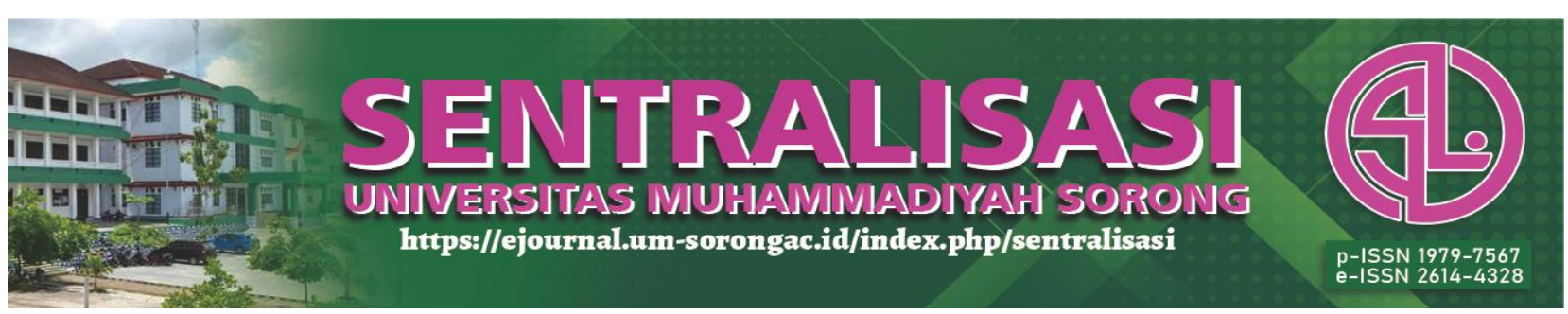

2013); (Kurniawan et al., 2017).

Company managers who have a high level of ownership of a company, it is possible to exercise discretion over company resources will be reduced. The reduction of indiscretion or company resources will ultimately affect the activities of the control holder of company resources so that the quality of Corporate Governance implementation will lead to resource savings from excessive activities that can be carried out. The concentration of ownership can indirectly affect the quality of governance within the company, namely through increasing discretionary resource activities within the company which will then influence policies in determining governance (Taman \& Nugroho, 2011). Increased concentration of ownership will increase Good Corporate Governance, therefore ownership concentration will affect Corporate Governance in a company (Hormati, 2009); (Sulyanti, 2011). Thus, thus the formulation of the first hypothesis is:

H1: Ownership concentration has a positive and significant effect on the quality of corporate governance. The larger the size of the company based on the number of ownership of assets, it means that more capital is invested and the circulation of money in circulation is also increasing. This causes the attention of investors to be more focused so that the company is encouraged to improve the quality of its governance to create trust in the company's reputation (Sulyanti, 2011)(Taman \& Nugroho, 2011). Based on this, the second hypothesis proposed is:

H2. Firm size has a positive and significant effect on the quality of corporate governance. Research conducted by Rahayuningsih (2013); Hormati (2009); Taman \& Nugroho (2011); Sulyanti (2011) shows that there is an influence between leverage and the implementation of corporate governance. the larger the portion of funding that comes from debt, the greater the opportunity to become a company that is considered profitable, so that the company becomes more motivated in improving the quality of its governance. Thus, the third hypothesis proposed in this study is: H3. Leverage has a positive and significant effect on the quality of corporate governance

\section{Research Design}

This study is empirical research with a quantitative approach. The subjects of this research are companies listed on the Indonesia Stock Exchange (IDX) with several criteria, including (1) LQ45 and CGPI indexed; (2) manufacturing and banking companies; (3) issue Corporate Governance reports and financial reports in rupiah currency; and (4) companies with assets valued at more than 1 trillion rupiahs. Based on the predetermined criteria, from the population in this study, which was 45 companies indexed by LQ45, 17 companies that met the requirements with a year of observation for 3 years (2017-2019).

The object of this research is secondary data obtained from corporate governance reports and the company's annual financial statements. The data were analyzed by multiple linear 


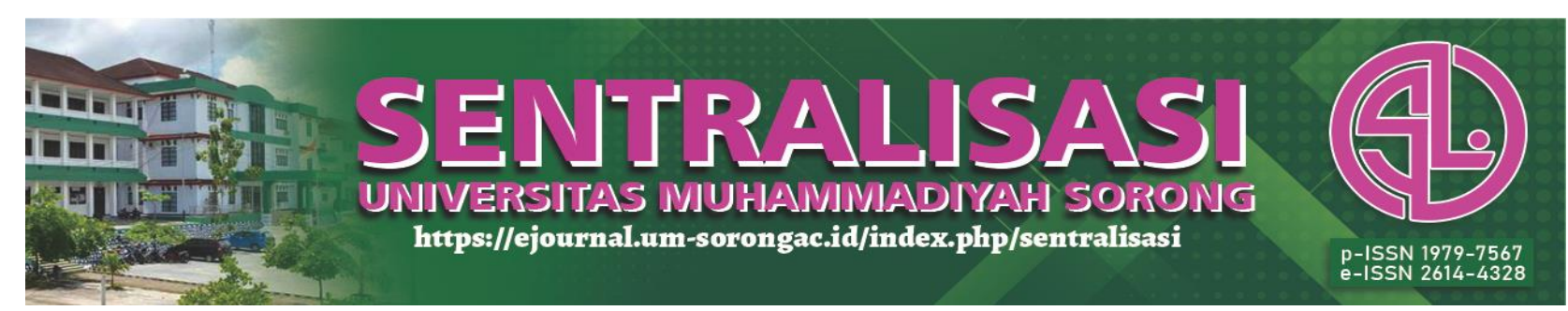

regression which was formulated as follows.

$Y=\alpha+\beta_{1} X_{1}+\beta_{2} X_{2}+\beta_{3} X_{3}+\varepsilon$

$G C G=\alpha+\beta_{1} O C+\beta_{2} S F+\beta_{3} L V+\varepsilon$

$$
\begin{aligned}
& \text { GCG = Good Corporate Governance } \\
& \text { OC = Ownership Consentration } \\
& \text { SF = Size of the Firm } \\
& \text { LV = Leverage }
\end{aligned}
$$

\section{Operational Definition and Variable Measurement}

The dependent variable used in this study is the Quality of corporate governance. Quality of Corporate Governance Implementation is a variable that is measured using an index developed by The Indonesian Institute for Corporate Governance (IICG) called the Corporate Governance Perception Index (CGPI). This measurement is used to determine the extent of the implementation of Good Corporate Governance in a company. Corporate Governance Perception Index (CGPI) by conducting an assessment using several indicators including (1) Shareholder Rights; (2) Boards of Directors; (3) Outside Directors; (4) Audit Committee and Internal Auditor; and (5) Disclosure to Investors. The score of each subindex is scored 1 if it meets and 0 if it does not meet.

There are three exogenous variables used, namely (1) ownership concentration, (2) firm size, and (3) leverage. The concentration of ownership is reflected in the comparison of the company's controllers, either partially or wholly. measurement of ownership concentration is the comparison between the largest share ownership owned by the company and the total outstanding shares. Company size variable which is the size scale of the company that is proxied based on the total assets owned. The leverage variable is the capital financing owned by the company based on the proportion of debt that is greater than the company's capital (the proportion of equity is smaller than the proportion of debt).

\section{Result and Discussion}

The research subjects used were 17 companies with 3 years of observation so that the total sample targeted for analysis was 51 with descriptive statistical values shown in table 1 below.

Table 1. Decriptive

\begin{tabular}{lcrrrr}
\hline & N & Min & Max & Mean & $\begin{array}{c}\text { Std. } \\
\text { Deviation }\end{array}$ \\
\hline Ownership Consentration & 51 & 0.10 & 0.93 & 0.59 & 0.177 \\
Size of The Firm & 51 & 29.85 & 34.89 & 32.16 & 1.571 \\
Leverage & 51 & 0.15 & 0.86 & 0.49 & 0.258 \\
Good Corporate Governance & 51 & 23.00 & 25.00 & 23.95 & 0.619
\end{tabular}




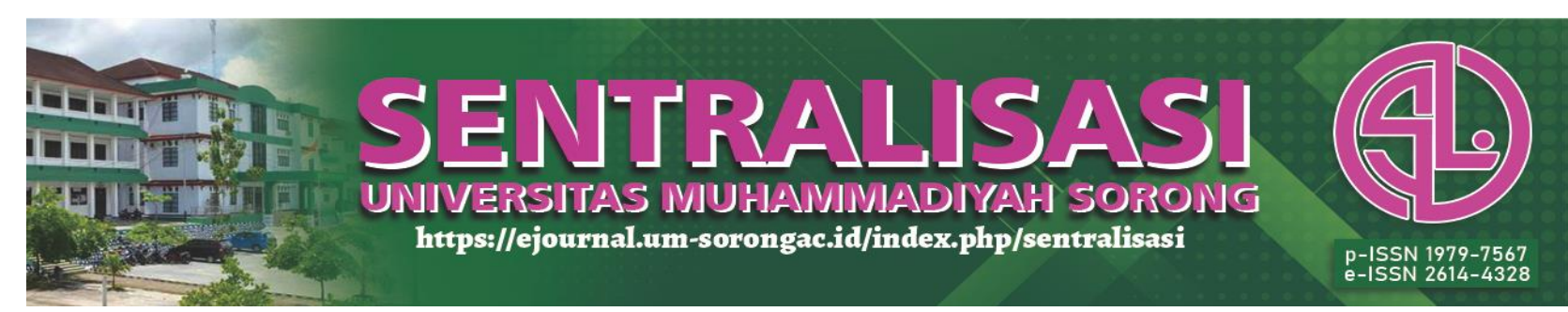

Valid N (listwise) 51

Source : Processed Data (SPSS output)

The results of the classical assumption test including the normality test, heteroscedasticity test, autocorrelation test, and multicollinearity test can be summarized in table 2 below.

Tabel 2. Classical Assumption Test Summary

\begin{tabular}{lll}
\hline & \multicolumn{1}{c}{ Test Result } & \multicolumn{1}{c}{ Description } \\
\hline Normality test & Asymp. Sig. (2-tailed) $=0.156$ & normal \\
Heteroscedasticity test & $\mathrm{OC}=0.869 ; \mathrm{SF}=0.872 ; \mathrm{LV}=0.975$ & symptom free \\
Autocorrelation test & $\mathrm{dU}<\mathrm{DW}<4-\mathrm{dU}: 1.675<1.728<2.325$ & symptom free \\
Multicollinearity test & Tolerance 0.947; 0.351;0.348; VIF $<10$ & symptom free
\end{tabular}

Source : Processed Data (SPSS output)

The KS test results to see the distribution of data shows the Asymp. Sig. (2-tailed) = $0.156>5 \%$. These results indicate that the data used are normally distributed and are suitable for use in the research model. The results of the heteroscedasticity test with the Glejser test above show that the ownership concentration has $\mathrm{p}$-value $=0.869$, the firm size has $\mathrm{p}$-value $=0.872$ and the leverage has $\mathrm{p}$-value $=0.975$. the three exogenous variables have a significance level greater than $5 \%$ so that it can be said that this model is free from heteroscedasticity problems.

The Durbin-Watson (DW) value is known to be 1.728, which means the value of DW is between the values of $\mathrm{dU}$ and $4-\mathrm{dL}(1.675<1.278<2.325)$. Thus, it can be said that autocorrelation is not a problem in this research model and this research deserves to be continued because one of the requirements of time series research is to be free from autocorrelation problems. The results of the multicollinearity test can be seen by looking at the tolerance value > 0.10 and the VIF value $<10.00$. It mean that there is no problem with multicollinearity symptoms.

Table 3. Determinant Coeficient

\begin{tabular}{ccccc}
\hline Model & $\mathrm{R}$ & R Square & $\begin{array}{c}\text { Adjusted R } \\
\text { Square }\end{array}$ & $\begin{array}{c}\text { Std. Error of the } \\
\text { Estimate }\end{array}$ \\
\hline 1 & 0.505 & 0.255 & 0.207 & 0.551 \\
\hline
\end{tabular}

Predictors: (Constant), OC, SF, LV

Source : Processed Data (SPSS output)

Coefficient of determination shows the ability of exogenous variables simultaneously in influencing endogenous variables. In the test results, the value of Adjusted R Square $=0.207$, which means that the three exogenous variables have an effect of $20.7 \%$ on the endogenous variables. While the rest $(100 \%-20.7 \%=79.3 .8 \%)$ is the influence of other factors outside of this research model.

A positive adjusted $\mathrm{R}$ square value indicates the feasibility of this research model to 


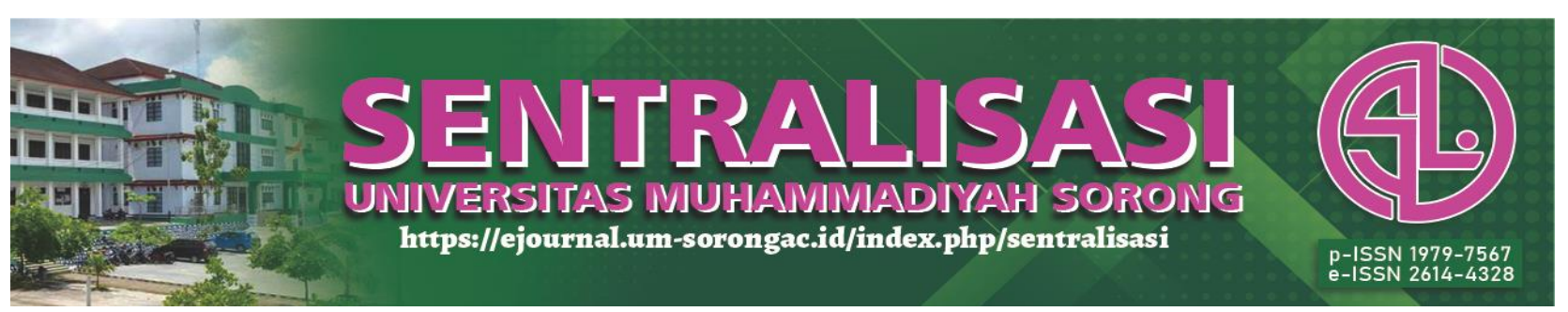

proceed to simultaneous testing with the F test.

Table 4. Simultaneous test

\begin{tabular}{cccccc}
\hline \multirow{2}{*}{ Model } & Sum of Squares & Df & Mean Square & F & Sig. \\
\hline 1 & 4.871 & 3 & 1.624 & 5.353 & $0.003^{\mathrm{b}}$ \\
& 14.256 & 47 & 0.303 & & \\
& 19.127 & 50 & & & \\
\hline
\end{tabular}

Dependen Variable: GCG

Predictors: (Constant). OC, SF, LV

Source : Processed Data (SPSS output)

Table 4 shows that $\mathrm{p}$-value $=0.003<0.05$ of the tolerance level, so as the basis for decision making, it can be concluded that the three eksogenous variables together affect the quality of corporate governance.

In answering the hypothesis, a partial test is used in multiple linear regression. test results are shown in Table 5 below.

Table 5. Partial Regression Test

\begin{tabular}{ccccccc}
\hline \multirow{2}{*}{ Model } & \multicolumn{2}{c}{ Unstandardized Coefficients } & $\begin{array}{c}\text { Standardized } \\
\text { Coeffisients }\end{array}$ & \multirow{2}{*}{$\mathrm{T}$} & Sig. \\
\cline { 3 - 5 } & B & Std. Error & Beta & & \\
\hline $1 \quad$ (Constant) & 16.934 & 2.559 & & 6.616 & 0.000 \\
& OC & 1.588 & 0.451 & 0.455 & 3.517 & 0.001 \\
& SF & 0.209 & 0.084 & 0.531 & 2.501 & 0.016 \\
& LV & -1.319 & 0.511 & -0.551 & -2.581 & 0.013 \\
\hline
\end{tabular}

Dependen Variable: GCG

Source : Processed Data (SPSS output)

Based on table 5, the results show where the variable of Ownership Concentration (X1) is 1.588. because the $\mathrm{p}$-value $=0.001>0.05$ probability, it can be concluded that there is influence between the concentration of ownership (X1) on the implementation of corporate governance (Y). Thus, the first hypothesis is accepted. These results indicate that the more concentrated share ownership, the more likely the company is to implement better corporate governance. ownership concentration is proxied from the ratio of the largest share ownership to the total outstanding shares. So the concentration of share ownership tends to increase the quality of the implementation of Corporate Governance. the results of this study are the same as those obtained Hormati (2009), Ramadhan and Laksito (2019).

Different results were shown in the second hypothesis test, in which the size of the 


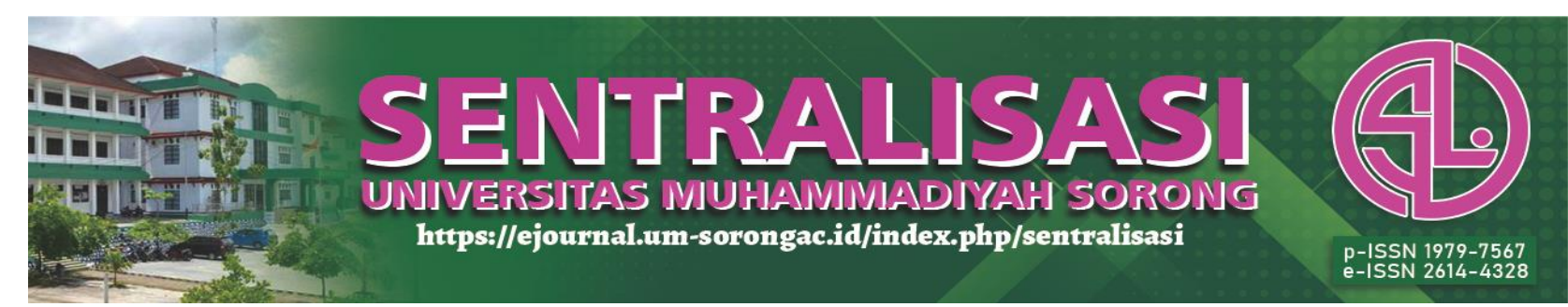

company $(\mathrm{X} 2)$ has a P-value $=0.016<$ Probability 0.05 , which means that there is a significant effect between size of the firm on the quality of corporate governance (Y). Thus, the second hypothesis proposed in this study can be accepted. The larger the size of a company, the better the quality of Corporate Governance implementation so that it becomes an attraction for investors to invest in the company. In addition, large companies will generally face more complicated problems, so that one way that is considered effective to overcome these problems is by implementing better Corporate Governance. The same results were obtained by (Hormati, 2009), (Sulyanti, 2011) (Ramadhan \& Laksito, 2019) in their research that the size of the firm has a positive influence in determining the quality of corporate governance.

While the third variable, namely leverage, has a P-value of $0.013>$ Probability of 0.05 , which means that there is influence of third eksogeneous (leverage - X3) on the Corporate Governance's Quality (Y). Thus, the third hypothesis is supported by the results. However, leverage shows a negative effect on corporate governance. The results of this study indicate that the greater the liability owned by the company will reduce the value of good corporate governance. This means that companies that have high leverage ratios tend not to apply good governance. The same results were obtained by (Sulyanti, 2011) and (Hormati, 2009).

\section{Conclusion}

The importance of implementing corporate governance in increasing the value of the company makes the company concentrate on looking at the factors that determine the improvement of its implementation. In the context of this study, of the three determinant variables that are thought to affect corporate governance's quality. This study has limited time in the data collection process, so that further research is expected to extend the observation time to 5 or even 10 years.

\section{Refferences}

Al-Shetwi, M. (2011). Impact Of Internal Audit Function (Iaf) On Financial Reporting Quality (Frq): Evidence From Saudi Arabia. African Journal Of Business Management, 5(27). Https://Doi.Org/10.5897/Ajbm11.1805

Aspan, H. (2017). Good Corporate Governance Principles In The Management Of Limited Liability Company. International Journal Of Law Reconstruction, I(1), 87-100.

Bone, F. La Ode Dan Ponto, Sahrul. 2017. Pengaruh Ukuran Perusahaan Dan Faktor Regulasi Terhadap Kualitas Implementasi Corporate Governance. Jurnal Manajemen Dan Akuntansi Future Hal. 99- 113.

Dallas, L. (2018). Is There Hope For Change? The Evolution Of Conceptions Of "Good" Corporate Governance. Ssrn Electronic Journal, 491-564. Https://Doi.Org/10.2139/Ssrn.3026266 


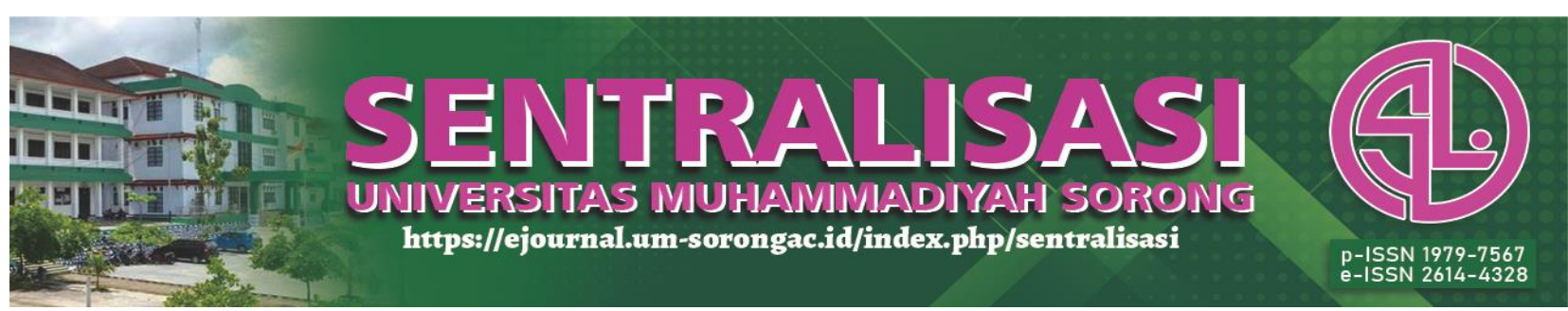

Franita, Riska. 2018. Mekanisme Good Corporate Governance Dan Nilai Perusahaan (Studi Untuk Perusahaan Telekomunikasi). Penerbit Lembaga Penelitian Dan Penulisan Ilmiah Aoli, Medan.

Hormati, A. (2009). Karakteristik Perusahaan Terhadap Kualitas Implementasi Corporate Governance. Jurnal Keuangan Dan Perbankan, 13(2), 288-298.

Jao, R., \& Pagalung, G. (2011). Terhadap Manajemen Laba Perusahaan Manufaktur Indonesia Robert Jao Gagaring Pagalung ( Universitas Hasanuddin ). Jurnal Akuntansi Dan Auditing, 8(1), 1-94.

Jensen, Michael C And Meckling, William H. 1976. Theory Of The Firm: Managerial Behavior, Agency Costs And Ownership Structure. University Of Rochester, Rochester, Ny 14627, U.S.A. Journal Of Financia Economics 3 Hal. 305-360

Kebon, S. M. A. M., \& Suryanawa, I. K. (2017). Pengaruh Good Corporate Governance Dan Investment Opportunity Set Pada Nilai Perusahaan Di Bursa Efek Indonesia. E-Jurnal Akuntansi, 20(2), 1534-1563. Https://Doi.Org/10.24843/Eja.2017.V20.I02.P24

Kurniawan, H., Fitrijanti, T., \& Irawady, C. (2017). Sistem Informasi, Keuangan, Auditing Dan Perpajakan. Sikap, 4(2), 98-106.

Meitha, R., \& Tuzahro, U. (2009). Determinan Corporate Governance. Jurnal Akuntansi Indonesia, 5(2), 273-286.

Praditha, R., Haliah, H., Habbe, A. H., \& Rura, Y. (2020). Do Investors Experience Heuristics In Earnings Forecasting? Business: Theory And Practice, 21(2), 686-694. Https://Doi.Org/10.3846/Btp.2020.12018

Rahayuningsih, D. (2013). Pengaruh Kesempatan Investasi, Konsentrasi Kepemilikan, Leverage, Komposisi Aktiva, Ukuran Perusahaan, Dan Faktor Regulasi Terhadap Kualitas Good Corporate Governance. Jurnal Dinamika Akuntansi, 5(2), 135-145. Https://Doi.Org/10.15294/Jda.V5i2.2994

Ramadhan, I., \& Laksito, H. (2019). Analisis Pengaruh Karakteristik Perusahaan Terhadap Kualitas Corporate Governance : Studi Empiris Pada Perusahaan Terdaftar Di Corporate Governance Perception Index Tahun 2012-2015. Diponegoro Journal Of Accounting, 8(4), 1-14.

Rura, Y. (2010). Pengungkapan Pro Forma, Mendukung Atau Menyesatkan Investor? Jurnal Akuntansi Multiparadigma, 1(3), 375-392. Https://Doi.Org/10.18202/Jamal.2010.12.7099

Sochib. 2016. Good Corporate Governance Manajemen Laba Dan Kinerja Keuangan (Studi Terhadap Good Corporate Governance, Manajemen Laba Dan Kinerja Keuangan Bank Umum Swasta Nasional Go Public Di Bei). Penerbit Deepublish (Grup Penerbit Cv Budi Utama), Yogyakarta.

Sulyanti, N. H. (2011). Pengaruh Ukuran Perusahaan, Tingkat Leverage, Kesempatan Investasi Dan Konsentrasi Kepemilikan Terhadap Kualitas Implementasi Good Corporate Governance. Universitas Diponegoro.

Taman, A., \& Nugroho, B. A. (2011). Determinan Kualitas Implementasi Corporate Governance Pada Perusahaan Yang Terdaftar Di Bursa Efek Indonesia (Bei) Periode 2004-2008. Jurnal Pendidikan Akuntansi Indonesia, 9(1), 1-23. 


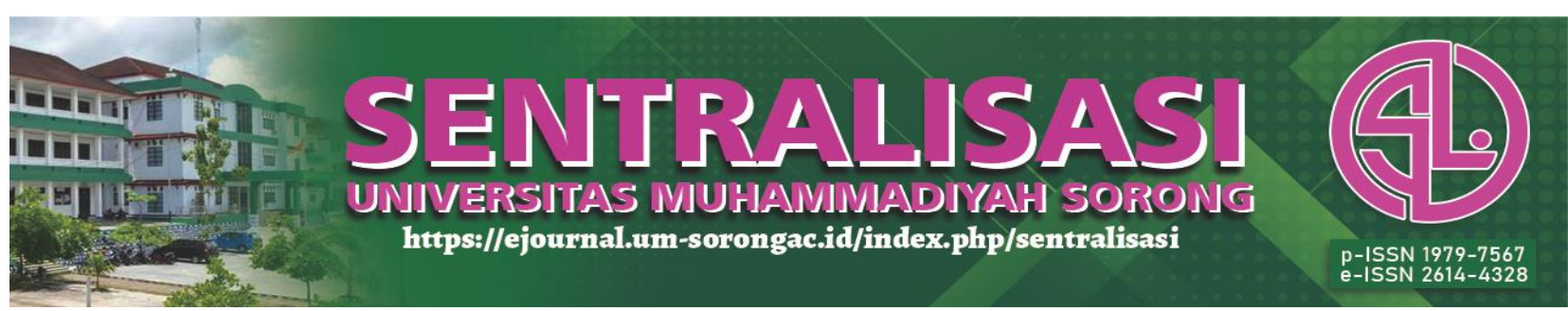

Wibowo, Edi. 2010. Implementasi Good Corporate Governance Di Indonesia. Jurnal Ekonomi Dan Kewirausahaan Vol.10, No.2, Hal. 129-138.

Worokinasih, S., \& Zaini, M. L. Z. B. M. (2020). The Mediating Role Of Corporate Social Responsibility (Csr) Disclosure On Good Corporate Governance (Gcg) And Firm Value. Australasian Accounting, Business And Finance Journal, 14(1 Special Issue), 88-96. Https://Doi.Org/10.14453/Aabfj.V14i1.9 